\title{
A new record of a tiger shrimp Penaeus monodon Fabricius, 1798 breeding female in the coast of Campeche, Mexico
}

\author{
Mario Alejandro Gómez-Ponce ${ }^{1}$, Nataly Bolaños-Martínez ${ }^{2}$, Píndaro Díaz-Jaimes ${ }^{2}$ \\ José Luis Bortolini-Rosales ${ }^{3} \&$ Pedro de Jesús Castellanos Pérez ${ }^{4}$ \\ ${ }^{1}$ Laboratorio de Ecología y Dinámica Poblacional de Camarón, Instituto de Ciencias del Mar \\ y Limnología, Estación El Carmen, Universidad Nacional Autónoma de México, Campeche, México \\ ${ }^{2}$ Laboratorio de Genética de Organismos Acuáticos, Instituto de Ciencias del Mar y Limnología \\ Universidad Nacional Autónoma de México, D.F., México \\ ${ }^{3}$ Departamento de Biología Comparada, Facultad de Ciencias \\ Universidad Nacional Autónoma de México, D.F., México \\ ${ }^{4}$ Biología Marina, Facultad de Ciencias Naturales, Universidad Autónoma del Carmen \\ Campeche, México \\ Corresponding author: Mario Alejandro Gómez Ponce (mgomez@ cmarl.unam.mx)
}

\begin{abstract}
The tiger shrimp Penaeus monodon is native to the Indo-West Pacific Ocean, covering the east coast of Africa, the Arabian Peninsula, Southeast Asia, Taiwan, China, the Sea of Japan, New Guinea and Australia. A new report was recorded on the capture in the wild of a female tiger shrimp P. monodon in conditions of reproductive maturity on the coast of Campeche in the Gulf of Mexico. The specimen was captured by a trawler operating near the coast of Campeche, in front of Carmen Island. The specimen was identified using dichotomous keys, additionally corroborated with analysis of the sequence of a fragment of 650 base pairs (bp) of the mitochondrial DNA (mtDNA) gene cytochrome oxidase I (COI), and compared with the sequence of $P$. monodon reported in GenBank. The specimen was deposited in the National Collection of Crustaceans of the Institute of Biology of the UNAM. Histological analysis of the gonads revealed that the organism was in a reproductive condition as ovaries contained oocytes in an advanced development state. The molecular data (sequenced fragments $\mathrm{F}$ and $\mathrm{R}$ ) were identical with the COI sequence of $P$. monodon deposited in GenBank, thus confirming the presence of $P$. monodon from the coasts of Isla del Carmen, Campeche.
\end{abstract}

Keywords: Penaeus monodon; tiger shrimp; genetic identification; introduced species; Gulf of Mexico

The giant or tiger shrimp Penaeus monodon inhabits the coast of Australia, Southeast Asia, south Asia and eastern Africa (Dore \& Frimodt, 1987; Pérez-Farfante $\&$ Kensley, 1997). This species matures and reproduces only in tropical marine habitats and spends its larval, juvenile, adolescent and sub-adult stages in estuaries, coastal lagoons or mangroves. In nature, it shows a marked nocturnal activity, burying itself in the bottom substrate during the day and emerging at night to search for food as a benthic consumer. Under natural conditions like other penaeid shrimps, tiger shrimp is an efficient predator more than an omnivorous or detritivorous scavenger (FAO, 2005-2019). Penaeus monodon is a species that has been cultivated for more than a century to provide food and sustenance economic income for coastal human populations in some Asian countries such as Indonesia, Philippines, Taiwan Province of China, Thailand and Vietnam. Research on its breeding has been conducted since 1970 through monoculture techniques in small ponds that were developed at the Tungkang Marine laboratory in Taiwan, Province of China, and partially at the Institut Français de Recherche pour l'Exploitation de la Mer (IFREMER; Pacific Ocean Center). Between 1980 and 1987 there has been an explosive boom of small-scale intensive farms in Taiwan due to commercial success in the development of formulated diets and due to the increase of the shrimp production for exportation to Japan (FAO, 2005-2019). The tiger shrimp has been reported in other areas outside its natural geographical

Corresponding editor: Ingo Wehrtmann 
distribution: in the west of Africa from Senegal to northern Angola (Knott et al., 2012), in South America from Colombia to Brazil (Fausto-Filho, 1987; Coelho et al., 2001; Santos \& Coelho, 2002; Aguado \& Sayegh, 2007; Altuve et al., 2008; Gómez-Lemos \& Campos, 2008; Cintra et al., 2011), Cuba, Puerto Rico and the Dominican Republic in the Caribbean (Knott et al., 2012; Giménez-Hurtado et al., 2013). In Mexican coasts, there exist reports by Morán-Silva et al. (2014) and Wakida-Kusonoki et al. (2013, 2016a, 2016b).

The presence of Penaeus monodon in southeastern United States of America was due to the escape of organisms from aquaculture areas, while in the South American countries it is mentioned that in addition to escapes from the cultivation areas, it was due to the transport and introduction of ballast waters by intercontinental vessels (Franklin, 2002; Atencio et al., 2006). The present work reports the finding of a female tiger shrimp off the coast of Isla del Carmen, corroborating a series of previous records reported by Wakida et al. (2013). In the present study, in addition to the species morphological identification, for the first time, there was included the species identification confirmed by genetic evidence as well as the reproductive condition for the captured specimen.

The tiger shrimp specimen was collected on 17 October 2015 by fishermen aboard an artisanal shrimp trawler boat operating near the coast of Campeche off Isla del Carmen (18'43'17.72” N; 91 $\left.{ }^{\circ} 55^{\prime} 32.0^{\prime \prime} \mathrm{W}\right)$. The specimen was placed on ice and transported for physical inspection to the "El Carmen" station of the Instituto de Ciencias del Mar y Limnología (ICMyL) at Universidad Nacional Autónoma de México (UNAM). The sex of the organism was determined by examining the gonads and registered the total length in $\mathrm{mm}$ (TL), carapace length (CL) and total weight in $\mathrm{g}(\mathrm{TW})$. Tissue samples were obtained from the sixth abdominal segment for the genetic identification of the organism, which was transported to the Genetics Laboratory of the ICMyL-UNAM, in Mexico City. The entire organism was preserved in $70 \%$ ethanol and sent to the Department of Comparative Biology of the Faculty of Sciences-UNAM, where the histological analysis of the gonads was performed. Finally, the specimen was deposited in the Crustacean National Collection of the Instituto de Biología-UNAM and was assigned the catalog number CNCR 30877.

The genomic DNA was extracted from muscle tissue using the Phenol-Chloroform protocol described by Sambrook et al. (1989). Universal primers LCO1490: 5'-GGGGTCAACAAATCATA AAGATA TTGGGG-3' ' and HCO2198: 5'-TAAACTTCAGGG GGGG GGTGACCAAAAAATCA-3' reported by Folmer et al. (1994) were employed to amplify a frag- ment of 650 base pairs (bp) from the mitochondrial DNA (mtDNA) region of the cytochrome oxidase I (COI). The PCR reactions were made in $15 \mu \mathrm{L}$ of final volume which consisted of 10 to $100 \mathrm{ng}$ of DNA, $1 \mathrm{X}$ of DreamTaq buffer $\left(1.5 \mu \mathrm{L}^{-1}\right), 200 \mu \mathrm{M} \mathrm{MgCl}_{2}, 0.15 \mu \mathrm{M}$

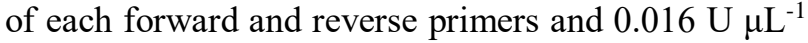
of DreamTaq Polimerasa. The cycling conditions consisted of denaturalization at $95^{\circ} \mathrm{C}$ for $60 \mathrm{~s}$, followed by 35 cycles of $95^{\circ} \mathrm{C}$ for $60 \mathrm{~s}$, annealing temperature of $52^{\circ} \mathrm{C}$ for $90 \mathrm{~s}$, extension temperature of $72^{\circ} \mathrm{C}$ for $60 \mathrm{~s}$ and a final extension step at $72^{\circ} \mathrm{C}$ for $5 \mathrm{~min}$. PCR products were visualized on $1 \%$ agarose gels and purified with the QIAquick ${ }^{\circledR}$ (Qiagen) kit and sent for sequencing to the Sequencing Unit at the Instituto de Biología-UNAM using both, forward and reverse primers. Both forward and reverse sequences obtained from the mtDNA-COI region were edited using Bioedit. A consensus sequence was generated using the contig option in Bioedit to corroborate each nucleotide position of the sequenced fragment. The consensus sequence was compared against the sequences available on the GenBank database (http://www.ncbi. nlm.nhi.gov) using a BLAST (Basic Local Alignment Search Tool) search to corroborate the identity of the specimen.

A portion of ovarian tissue from the $2^{\text {nd }}$ and $3^{\text {rd }}$ abdominal segments was extracted to perform the histological procedure. The tissue was post-fixed with $10 \%$ neutral formaldehyde and further immersed in Davidson's fixative for an additional period of $72 \mathrm{~h}$. The tissue was washed for $3 \mathrm{~h}$ in running water and dehydrated through graded alcohols. Inclusion was carried out in paraplast using a melting point of 56$58^{\circ} \mathrm{C}$ and cuts obtained with a thickness of $5 \mu \mathrm{m}$, which were stained with the Hematoxylin-Eosin technique. Cuts were finally mounted with synthetic resin (Bell \& Lightner, 1988). Additionally, fresh samples of oocyte were taken and stained using the acetorcein technique (Martínez-Gómez et al., 2005).

The collected organism corresponded to a female with a total length of $345 \mathrm{~mm}$, a carapace length of 122 $\mathrm{mm}$ and a total weight of $230 \mathrm{~g}$ (Fig. 1a). For species identification, the external morphological characters proposed by Dall et al. (1990) and Pérez-Farfante \& Kensley (1997) were fully corroborated. The specimen was a closed-type telic with the fifth pair of pereiopods without exopods, horizontally straight hepatic carina, and gastro-orbital carina occupying the posterior half of the distance between the hepatic spine and the postorbital margin of the carapace (FAO, 2005-2019).

The consensus sequence obtained from both sequenced fragments $\mathrm{F}$ and $\mathrm{R}$ resulted in a $678 \mathrm{bp}$ fragment for the mtDNA-COI region, which when compared to the GenBank database resulted in a $100 \%$ 


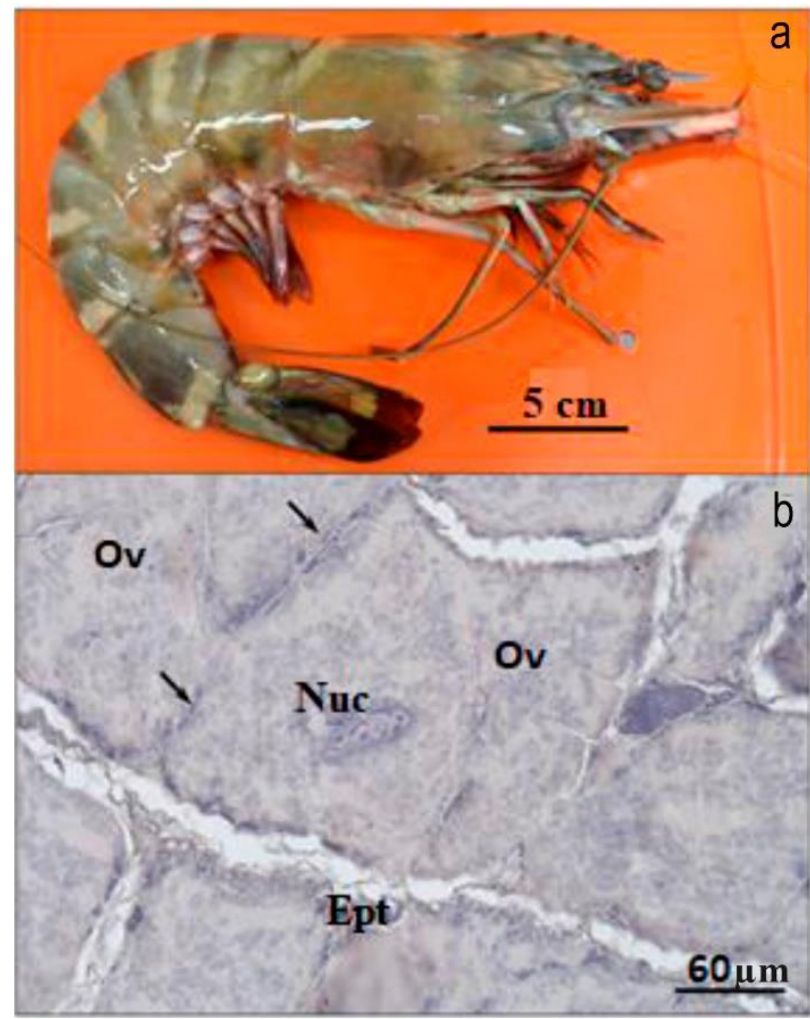

Figure 1. a) Penaeus monodon collected in front of Punta de las Disciplinas at the coast of Campeche, Mexico, b) ovaries' histological section of the specimen where oocytes are observed in an advanced stage of development. Ov, ovocites; Nuc, nuclei; Ept; epithelial tissue surrounding oocytes packages; arrows: follicular cells; flattened shape refers to terminal stages of maturation and little space within the ovary that are close to spawning.

of identity to the COI sequence of Penaeus monodon (Access $\mathrm{N}^{\circ} \mathrm{KF} 604892.1$ ) with a coverage of $100 \%$ of the sequenced bases (Fig. 2).

The two ovaries were well developed. From the histological examination, the tissue showed oocytes in advanced development (Bell \& Lightner, 1988; AlfaroMontoya et al., 2015) with histological characteristics typical for reproducing females, indicating that it was a female with reproductive capacity (Fig. 1b).

The tiger shrimp P. monodon is a decapod crustacean originated in the tropical zone of the Indo-Pacific, displaying a limited distribution to the western Pacific and the east coast of Africa. This decapod shrimp has presented wide dissemination mainly for aquaculture purposes explaining its presence in the American continent, specifically in Panama and the Dominican Republic, in 1976 and 1985, respectively (Welcome, 1988). There have also been records of $P$. monodon along the coast of the United States of America (Fuller et al., 2014), which has been attributed to the involuntary release of farms into the Gulf of Mexico due to the storms and hurricanes present in the region (Altuve et al., 2008). Considering that in Mexico the tiger shrimp are not used in breeding farms, it is probable that the presence of the species in Mexican waters is due to the existence of a migration route between the northern Gulf of Mexico, where the species has previously been established in the wild (Knott et al., 2012). The displacement of organisms outside their natural geographical distribution area is one of the most significant components of global changes induced by human activities (Altuve et al., 2008). The introduction of species of different origins in specific habitats is the cause of major alterations in natural ecosystems leading to loss of biodiversity. Rodríguez (2001) mentioned that when invasive species reach an environment in which they lack natural predators, they become a real risk impacting biodiversity since native species have no defense against invaders (predators, pathogens, competitors or parasites), which become a new and sudden selective force. Also, most of the time, invasive species carry associated parasites, as is the case of the copepod, Pseudodiaptomus trihamatus, which was supposedly introduced into Brazilian waters as a host of the tiger shrimp (Henriques et al., 2006). Other factors that may be involved in the reduction of wild populations is when the arrival of invasive species leads to an imbalance in ecosystems due to the competition they represent for native species as they promote the creation of new niches, affecting the ecological dynamics of an ecosystem and causing new competition stress in some species in the impacted area(s) (Knott et al., 2012; Alfaro-Montoya et al., 2015). Some consequences of this could be the decline of populations, including the species' genetic diversity (Grosholz, 2002; Gallardo et al., 2015). This last may affect the adaptive response capacity of populations, especially when these are reduced in size because of the competition. Decapod crustaceans are well-adapted organisms due to their anatomy, osmotic resistance and high fecundity, which allow them to successfully colonize new areas and establish new populations rapidly (Rodríguez \& Suárez, 2001). The presence of numerous reports for this species on the coasts of the Gulf of Mexico raises the question about whether this species has reached a population size that can impact local populations of other shrimp species. An analysis of this question would be possible through the continuous monitoring of the species in the Gulf of Mexico, and by increasing the sampling efforts. Similarly, other research topics need to be investigated, such as the analysis of parasites present in collected organisms determining their trophic level, the dispersal dynamics of their larvae and postlarvae, their presence in coastal zones and their entrance capability into coastal lagoons. 


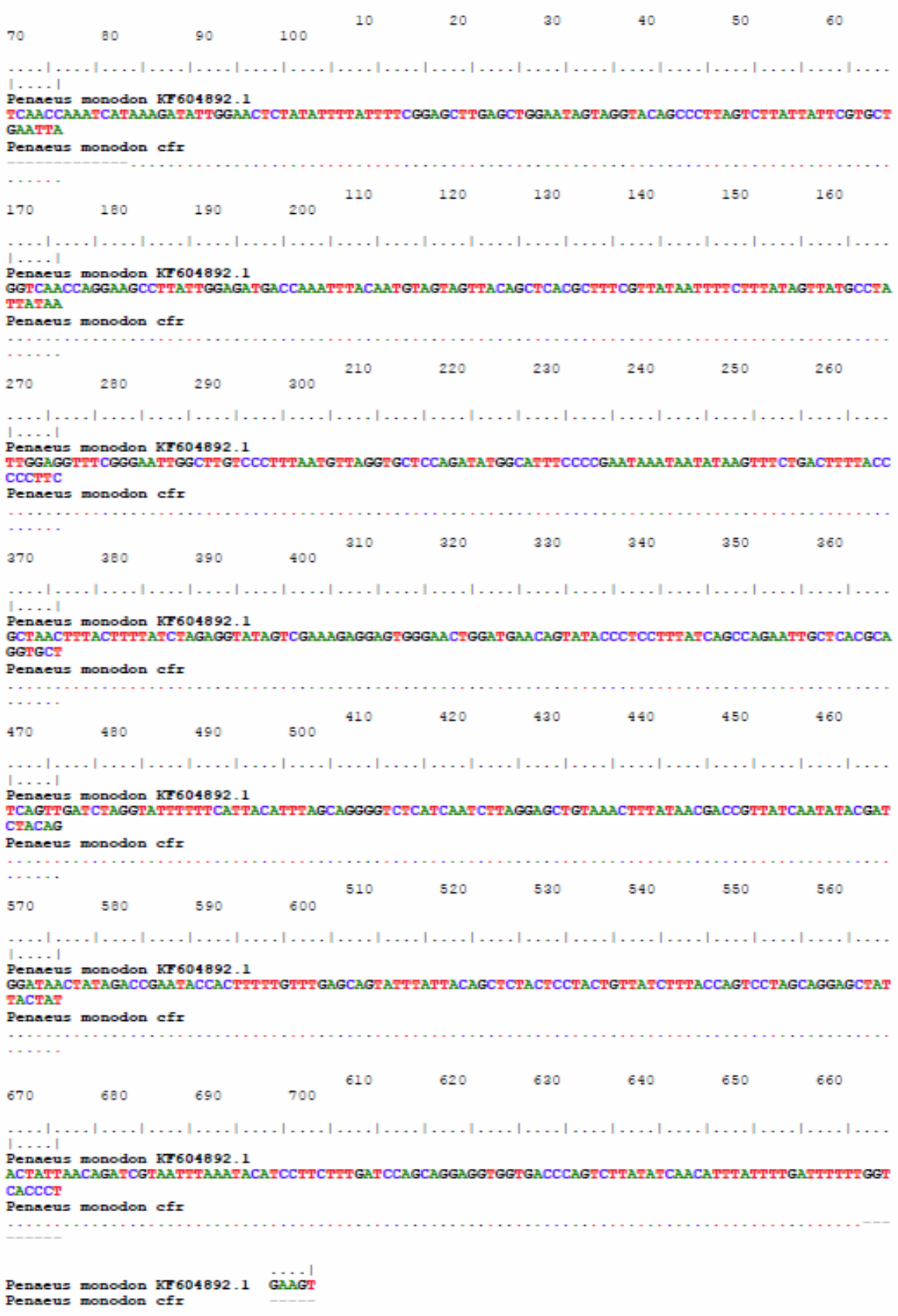

Figure 2. Alignment of the P. monodon mtDNA-COI region sequence (GenBank KF604892.1) and the specimen collected in Punta de las Disciplinas, Campeche, Mexico. Colored dots under the nucleotide sequence corresponding to the similarities between the two sequences.

The results from the different analyzes applied in the present study corroborated the presence of a female of $P$. monodon off the coast of Isla del Carmen, Campeche; it is the first time that morphological identi- fication is corroborated by molecular data, relevant considering the difficulties of species identification using only external morphological characteristics. The results of the molecular analysis confirmed the morpho- 
logical identification, which resulted in a $100 \%$ identity percentage to the COI sequence of $P$. monodon with coverage of $100 \%$ of the sequenced bases. Likewise, the histological analysis showed two well-developed ovaries with oocytes in advanced development, indicating that it was a female with reproductive capacity.

\section{ACKNOWLEDGMENT}

We thank the fishermen of Isla del Carmen, especially Mr. Miguel Ángel Benítez, who collected the shrimp.

\section{REFERENCES}

Aguado, G. \& Sayegh, J. 2007. Presencia del camarón tigre gigante Penaeus monodon (Crustacea, Penaeidae) en las costas del Estado Anzoátegui, Venezuela. Boletín del Instituto Oceanográfico de Venezuela, 46(2): 107-111.

Alfaro-Montoya, J., Monge-Ortiz, A.M., MartínezFernández, D. \& Herrera-Quesada, E. 2015. First record of the nonindigenous Penaeus monodon Fabricius, 1798 (Penaeidae) in the Caribbean Sea of Costa Rica, Central America, with observations on selected aspects of its reproductive biology. Bioinvasions Records, 4(3): 217-222. doi: 10.3391/bir. 2015.4.3.11

Altuve, D.E., Marcano, L.A., Alió, J.J. \& Blanco-Rambla, J.P. 2008. Presencia del camarón tigre Penaeus monodon Fabricius, 1798 en la costa del delta del Río Orinoco y Golfo de Paria, Venezuela. Memorias de la Fundación La Salle de Ciencias Naturales, 68: 8392.

Atencio, M., Morán, R. \& Jurado, J. 2006. Presencia de Penaeus monodon (Crustacea: Decapoda: Penaeidae) en aguas del Golfo de Venezuela. Congreso Colombiano de Acuicultura, Universidad Magdalena, Santa Marta, pp. 160-161.

Bell, T.A. \& Lightner, D.V. 1988. A handbook of normal penaeid shrimp histology. World Aquaculture Society, Baton Rouge.

Cintra, I.H.A., Paiva, K.S., Botelho, M.D.N. \& Silva, K.C.A. 2011. Presence of Penaeus monodon in the continental shelf of the State of Para, Northern Brazil (Crustacea, Decapoda, Penaeidae). Journal Agriculture and Environmental Science, 54(3): 314-317. doi: 10.4322/rca.2012.028

Coelho, P.A., Ferrao-Santos, M.C. \& Ramos-Porto, M. 2001. Ocorrência de Penaeus monodon Fabricius, 1798 no litoral dos estados de Pernambuco e Alagoas (Crustacea, Decapoda, Penaeidae). Boletim Técnico Científico da CEPENE, 9(1): 149-153.
Dall, W., Hill, B., Rothlisberg, P.C. \& Sharples, D.J. 1990. The biology of the Penaeidae. Academic Press, London.

Dore, I. \& Frimodt, C. 1987. Penaeus latisulcatus. An illustrated guide to shrimp of the world. Osprey Books, New York.

Food and Agriculture Organization (FAO). 2005-2019. Penaeus monodon. Cultured aquatic species information programme. FAO Fisheries and Aqua-culture Department, FAO, Rome. [http://www. fao.org/ fishery/culturedspecies/Penaeus_monodon/en]. Reviewed: March 5, 2019.

Fausto-Filho, J. 1987. Registro da captura de Penaeus monodon Fabricius no litoral do estado do Maranhão, Brasil (Crustacea: Penaeidae). Arquivos de Ciencia do Mar, 26: 81-82. doi: 10.32360/acmar. v26i1-2.314444

Folmer, O., Black, M., Hoeh, W. \& Vrijenhoek, R. 1994. DNA primer for amplification of mitochondrial cytochrome C Oxidase subunit I from diverse metazoan invertebrates. Molecular Marine Biology and Biotechnology, 3(5): 294-299.

Franklin, W. 2002. Penaeus monodon volta a aparecer no litoral Cearense. Revista Panorama Aqüicultura, 12(72): 9-11.

Fuller, P.L., Knott, D.M., Kingsley-Smith, P.R., Morris, J.A., Buckel, C.A., Hunter, M.E. \& Hartman, L.D. 2014. Invasion of Asian tiger shrimp, Penaeus monodon Fabricius, 1798, in the western North Atlantic and Gulf of Mexico. Aquatic Invasions, 9: 59-70.

Gallardo, B., Clavero, M., Sánchez, M.I. \& Villa, M. 2015. Global ecological impacts of invasive species in aquatic ecosystems. Global Change Biology, 22: 151-163.

Giménez-Hurtado, E., Pérez-Jar, L., Jaime-Ceballos, B., Fraga-Castro, I., Jiménez-Cabrera R., CabreraVilaon, D. \& Moreno-Urquiza, A. 2013. Capturado el camarón tigre Penaeus monodon (Fabricius, 1798) en las costas de Cuba. El Bohío, 3(2): 28-32.

Gómez-Lemos, L.A. \& Campos, N.H. 2008. Presencia de Penaeus monodon Fabricius (Crustacea: Decapoda: Penaeidae) en aguas de La Guajira Colombiana. Bulletin of Marine and Coastal Research, 37(2): 221225.

Grosholz, E. 2002. Ecological and evolutionary consequences of coastal invasions. Trends in Ecology and Evolution, 17(1): 22-27.

Henriques, D.M.F., Mendonça, J.M.S., Mendonça, K.R., Pereira, M.S., Faustino, G.V.B. \& Medeiros, G.F. 2006. Estudo da dispersão do copépodo exótico Pseudodiaptomus trihamatus (Wright, 1937) no 
Litoral do RN, PBePE Brasil. VI Congresso Brasileiro de Zoologia, Londrina.

Knott, D.M., Fuller, P.L., Benson, A.J. \& Neilson, M.E. 2012. Penaeus monodon. Nonindigenous aquatic species database. U.S. Geological Survey, Florida. [http://nas.er.usgs.gov/queries/factsheet.aspx?Speci esID=1209]. Reviewed: August 17, 2018.

Martínez-Gómez, P., Sánchez-Pérez, R., Vaknin, Y., Dicenta, F. \& Gradziel, T.M. 2005. Improved technique for counting chromosomes in almond. Scientia Horticulturae, 105(1): 139-143. doi: 10.1016/j.scienta.2005.01.019

Morán-Silva, A., Jiménez-Badillo, M.L., Cházaro-Olvera, S., Meiners-Mandujano, C., Galindo-Cortes, G. \& Oviedo-Perez, J. 2014. First record of tiger shrimp (Penaeus monodon Fabricius, 1798), in the southcentral coast of Veracruz, Gulf of Mexico. BIOCYT Biología, Ciencia y Tecnología, 7(28): 509-514.

Pérez-Farfante, I. \& Kensley, B. 1997. Penaeoid and sergestoid shrimps and prawns of the world. Keys and diagnoses for the families and genera. Mémoires du Muséum National d'Histoire Naturelle, 175: 1233.

Rodríguez, J.P. 2001. La amenaza de las especies exóticas para la conservación de la biodiversidad suramericana. Interciencia, 26(10): 479-483.

Rodríguez, G. \& Suárez, H. 2001. Anthropogenic dispersal of decapods crustaceans in aquatic environments. Interciencia, 26(7): 282-288.

Sambrook, J., Fritsch, E.F. \& Maniatis, T. 1989. Molecular cloning: a laboratory manual. Cold Spring Harbor Laboratory Press, New York.

Received: 15 April 2019; Accepted: 8 September 2019
Santos, M.C.F. \& Coelho, P.A. 2002. Espécies exóticas de camarões peneídeos (Penaeus monodon Fabricius, 1798 e Litopenaeus vannamei Boone, 1931) nos ambientes estuarino e marinho do nordeste do Brasil. Boletín Técnico Científico, 10(1): 209-222.

Wakida-Kusunoki, A.T., De Anda-Fuentes, D. \& LopezTellez, N.A. 2016a. Presence of giant tiger shrimp Penaeus monodon (Fabricius, 1798) in eastern Peninsula of Yucatan coast, Mexico. Latin American Journal of Aquatic Research 44(1): 155-158. doi: 10.3856/vol44-issue1-fulltext-16

Wakida-Kusunoki, A.T., Medina-Quijano, A.H. \& RojasGonzález, I. 2016b. Presence of tiger shrimp Penaeus monodon in the Chelem Lagoon, Yucatan, Mexico. Ciencia Pesquera, 24(2): 53-57.

Wakida-Kusunoki, A.T., Rojas-González, R.I., GonzálezCruz, A., Amador-del Ángel, L.E., Sánchez-Cruz, J.L \& López-Téllez, N.A. 2013. Presence of giant tiger shrimp Penaeus monodon Fabricius, 1798 on the Mexican coast of the Gulf of Mexico. Bioinvasion Records 2(4): 325-328. doi: 10.3391/ bir.2013.2.4.11

Welcome, R.L. 1988. International introductions of inland aquatic species. FAO Fisheries Technical Paper, 294: 318 pp. [http://www.fao.org/3/X5628E/X562 8E00.htm]. Reviewed: March 10, 2019. 